\title{
Placing Transdisciplinarity in Context: A Review of Approaches to Connect Scholars, Society and Action
}

\author{
Corrine Nöel Knapp ${ }^{1, * \mathbb{C}}$, Robin S. Reid ${ }^{2,3}$, María E. Fernández-Giménez ${ }^{2,4}$, Julia A. Klein ${ }^{3}$ (D) \\ and Kathleen A. Galvin 5 \\ 1 Haub School of Environment \& Natural Resources, University of Wyoming, 1000 E. University Ave., \\ Laramie, WY 82071, USA \\ 2 Center for Collaborative Conservation, Colorado State University, Fort Collins, CO 80523, USA \\ 3 Department of Ecosystem Science \& Sustainability, Colorado State University, Fort Collins, CO 80523, USA \\ 4 Department of Forest \& Rangeland Stewardship, Colorado State University, Fort Collins, CO 80523, USA \\ 5 Department of Anthropology, Colorado State University, Fort Collins, CO 80523, USA \\ * Correspondence: corriek.knapp@uwyo.edu; Tel.: +1-303-810-2985
}

Received: 10 July 2019; Accepted: 4 September 2019; Published: 7 September 2019

check for updates

\begin{abstract}
Complex sustainability problems (e.g., climate change) are challenging to understand and manage, leading to an increase in approaches that connect scholars to society and research to action (collaborative approaches). The transdisciplinary approach (TDA) represents one such approach. While TDA is new to many, there are several prior collaborative approaches including collaborative adaptive management, knowledge integration, participatory action research, and indigenous/local knowledge. Other contemporary and parallel approaches include citizen science, translational science, evidence-based practice, and knowledge with action. The varied disciplinary roots and problem areas contribute to a lack of interaction among these parallel but distinct approaches, and among the scholars and stakeholders who practice them. In this paper, we consider the connections, complementarities and contradictions among these distinct but related collaborative approaches. This review offers insights into the interaction between science and practice, including the importance of social processes and recognition of different ways of knowing, as well as how to conduct collaborative approaches on a variety of scales and think about how to generalize findings. The review suggests a need to rethink roles and relationships in the process of knowledge co-creation, both extending the roles of researchers and practitioners, creating new hybrid roles for "pracademics", and placing greater awareness on issues of power.
\end{abstract}

Keywords: transdisciplinary; co-production; antecedents; knowledge integration; participatory action research; indigenous knowledge; local knowledge; citizen science; translational science; evidence-based practice; knowledge with action

\section{Introduction}

"Wicked" sustainability problems, defined as problems that are multi-dimensional, appear intractable, and for which there is no one clear solution, are increasing in number and intensity [1]. These problems differ fundamentally from technical problems that can be isolated and controlled using standard scientific methodologies. The unique characteristics of knowledge production that can address complex sustainability problems were first defined by Gibbons and Nowtony in their formulation of "Mode 2" knowledge [2,3]. "Mode 2" knowledge was defined as knowledge production that is applied, integrates multiple disciplines and stakeholders, is reflexive, and which offers novel ways to assess quality [2]. In this paper, we consider the transdisciplinary approach (TDA) $[4,5]$ as part of a suite of collaborative approaches that connect research with action and that have increased in 
popularity, funding, and application in recent years [6,7]. In this paper, we explore multiple antecedent and contemporary collaborative approaches to knowledge production and highlight how they might strengthen and inform TDA. This review reveals the network that Gibbons and Nowtony proposed as an as-yet-unconsolidated, but diverse and growing body of collaborative approaches that suggest evolution in the practice and processes of science.

Transdisciplinarity connects diverse knowledge holders with one another and the realm of practice, shares power within the process, and arrives at different outcomes including action and problem management. It is a varied and shifting approach, but some characteristics are common across most applications. The first characteristic of this approach is its innate interdisciplinarity, which emerges from pursuing questions that require multiple disciplines to understand. TDA is concerned with action and seeks to understand a problem arena from multiple perspectives to assess and respond to it effectively.

The second characteristic of TDA is adoption of a process of knowledge co-production. Co-production is the process of knowledge creation that occurs between disparate knowledge producers interested in creating applied and useful knowledge. While co-production has emerged from several disciplines (sustainability science, public administration, and science and technology studies), common practices include engagement of diverse participants, attention to power and process, and reflexivity [8]. Co-production recognizes that shifting the process of science requires altering power relations between scientists and citizens [2]. Co-production demonstrates a commitment to knowledge democracy and to equalizing power in the process of creating and sharing knowledge [9]. In this paper, we define co-production as a process of knowledge creation attuned to both local (sharing knowledge) and larger (influencing governance structures to facilitate it) problem-solving [10].

The third characteristic of TDA is the types of outcomes that it facilitates, from action to problem management and capacity building. Outcomes from TDA should be useful in real world application and supported by rigorous scholarship [11]. While solutions-oriented outcomes are often the stated goals of TDA, Scholz and Steiner (2015a) acknowledge that in practice, outcomes often include important intermediate outcomes like capacity building, consensus building, mediation, and legitimization [12]. Among the most important and challenging outcomes of TDA are applied actions to manage some of the most critical sustainability challenges of our time.

The term "transdisciplinarity" was initially introduced in a 1970 seminar by the Swiss psychologist Jean Piaget, with the term increasing in use over time [13]. Researchers in health and medicine were some of the first to adopt this approach $[14,15]$. Within TDA, three separate discourses have been identified, each emerging from a different disciplinary base: a science-policy approach emerging from sociology (e.g., [3]), a systems approach from education and innovation (e.g., [16]) and a solution-based framing from environmental sustainability and health (e.g., [17]). While some of the collaborative approaches we review in this paper correspond to these TDA antecedents, others have developed separately. For instance, knowledge with action is aligned with the science-policy discourse, while participatory action research and collaborative adaptive management come from the solution-based approach. In this paper, we follow the European tradition of denoting TDA as both cross-disciplinary and working with societal actors, although we acknowledge that in the US TDA has often been defined as synonymous with interdisciplinary research [13].

Funders and platforms such as Future Earth [18], the Programme for Ecosystem Change and Society [19], and the Belmont Forum embrace this approach, and encourage researchers to adopt it. Policy decisions that have been influenced by this approach include the sustainable development realm [20], biodiversity [21] and European Union science policy [22]. As complex challenges abound and funding for TDA increases, more scholars are adopting it and using it to inform policy decision-making. As TDA expands its reach and scale, it is critical to reflect on what multiple approaches for connecting knowledge to action mean for building sustainable outcomes and processes on which the future of the planet and humanity depends. 
Critiques of TDA center around process, power and generalizability. TDA has diverse manifestations that use different processes and levels of knowledge integration [21]. Some have cautioned against labeling all academic-practitioner collaborations as 'transdisciplinary' [12], while others express concern that too little attention is paid to the TDA process $[9,23]$. Power asynchronies among participants can interfere with the success of the TDA process [24] and practitioners of TDA do not always fully consider power [4,25]. Finally, Westberg and Polk (2016) caution that TDA-produced action-related knowledge is specific to the 'micro-context' of the TDA practice [11] and cannot be generalized, although the process of TDA can be [26].

In this paper, we aim to inform and strengthen TDA practice by reviewing eight parallel collaborative approaches that seek to bridge knowledge and action. This review allows us to explore common themes across approaches. We believe that establishing this historical and broader perspective will strengthen TDA by revealing common practices and weaknesses from collaborative approaches, learning from the strengths of other approaches, and suggesting places for further cross-approach learning. In addition, connecting TDA practitioners to antecedents and other contemporary approaches may help to answer some of the critiques that have emerged in TDA (see above), and enhance TDA to make it more relevant, salient and legitimate. We focus on approaches with roots and applications in a diversity of disciplines, but that have been applied in natural resources/conservation, since the authors all work in this field. Although natural resources/conservation provided our lens for looking at collaborative approaches we believe that the implications apply to a broader range of fields that want to connect scholars with society to address real-world issues.

\section{Methods}

This paper began during a retreat of the research subcommittee of the Center for Collaborative Conservation, based at Colorado State University. In our discussions, questions about the roots of transdisciplinarity emerged, as well as intersections with other approaches that the author team was familiar with. As social-ecological scholars, primarily rooted in natural resources and conservation, we were familiar with many of these approaches and had published in these fields. In the course of our discussions, we identified the eight approaches reviewed here. Prior to submission for publication, we requested three friendly reviews from other sustainability science scholars to review the paper and offer suggestions. There was consensus that the approaches reviewed were representative of approaches that work to connect scholars and society for applied actions in the natural resource and conservation fields. Based on author expertise and familiarity, we each chose 1-2 approaches to review for this paper. The review was based on baseline understanding of each approach and a broad reading of the literature. For each approach, we looked to address goals and outcomes, the scale at which they are applied, how they address issues of power, and how they might inform one another and the future of TDA research and practice.

To better understand the approaches in relation to one another, we drafted several figures included in the text. For Figure 1, we conducted a search in Web of Science for keywords associated with each of the reviewed approaches (see Appendix A for a full list of keywords). We then created a stacked histogram based on these numbers of published papers for each approach over time. We acknowledge that there might be other related work which could have used similar but different terminology to describe the application of a similar or same method. For Figure 2, we established the timeline using the first published article found for each approach from the Web of Science search. Major fields associated with each approach were assessed through a literature review and knowledge of each field by the author team. For Figures 3 and 4, we compared reviewed approaches on a series of attributes. The authors completed a thorough literature review for the paper, as well as using these approaches in prior work, and thus were familiar with the scale of each approach, level of power sharing, level of inclusivity, and relative focus on research vs. action demonstrated in published articles from each approach. The authors most familiar with each approach set the numerical range for each approach based on their knowledge of the literature. Solid lines were based on where the 
field is currently, and dotted lines represent the aspirational direction of various approaches based on internal discussions within each approach and trends in each. Once experts on each approach had provided these numbers, we reviewed their placement as a team to make sure that the relative ranges were accurate based on the authors' collective knowledge. While not precise, these qualitative representations are useful for comparing these approaches to one another.

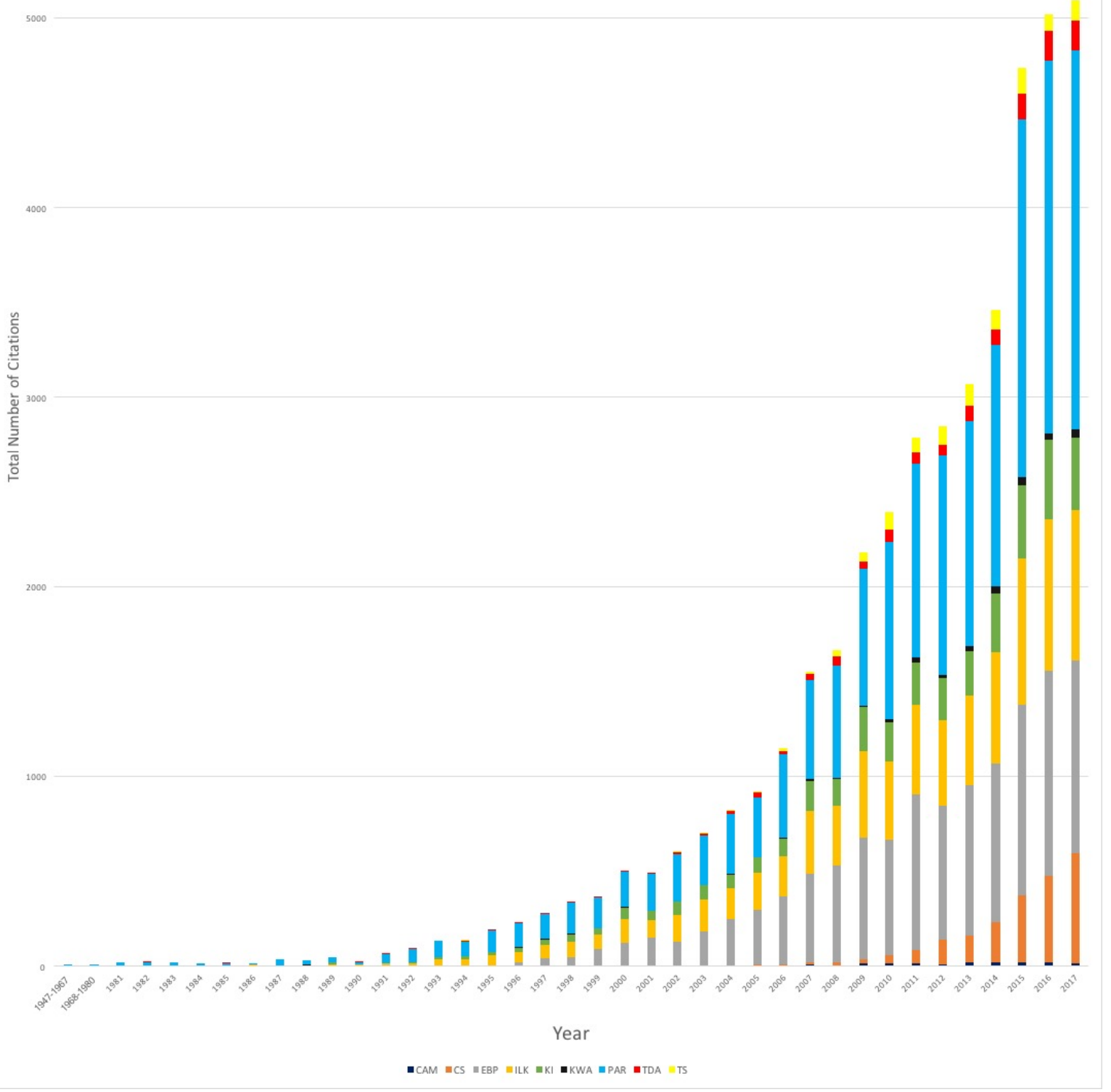

Figure 1. Total number of citations for each approach reviewed by year of publication. 
First publication using term

FIELD NAME Field contributing to approach

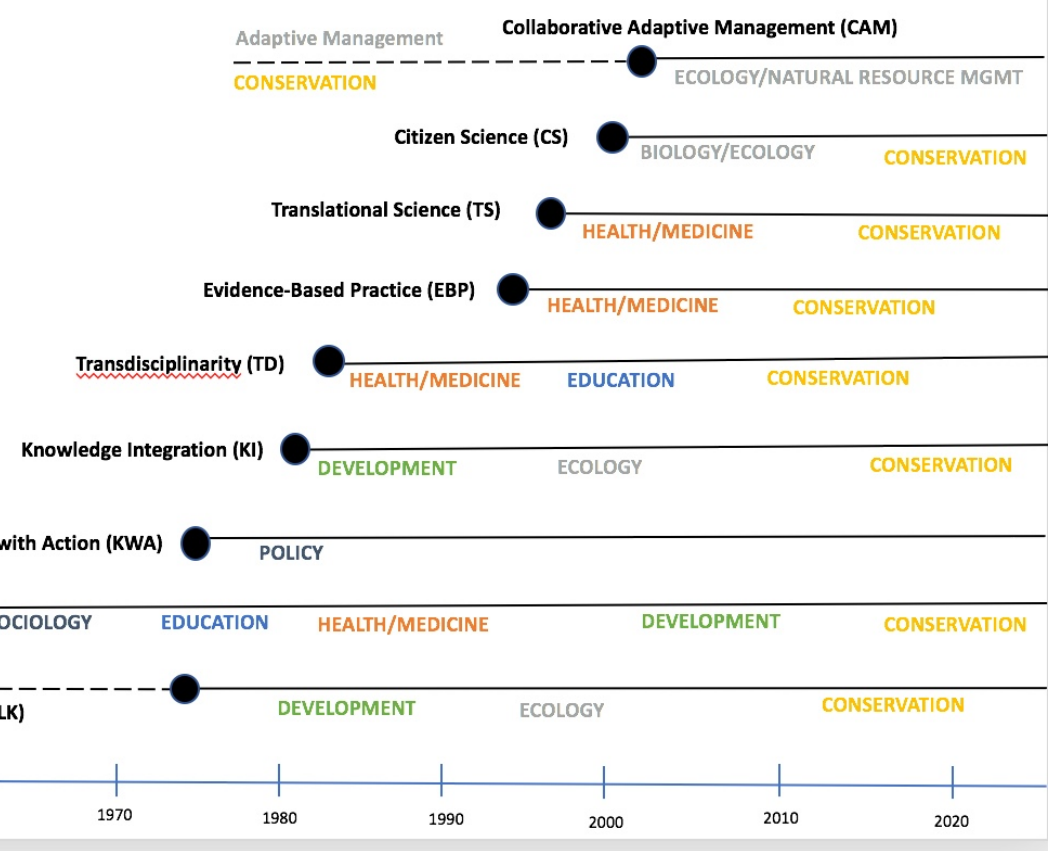

Figure 2. Timeline of reviewed approaches showing year of first publication and major fields contributing to the approach over time.

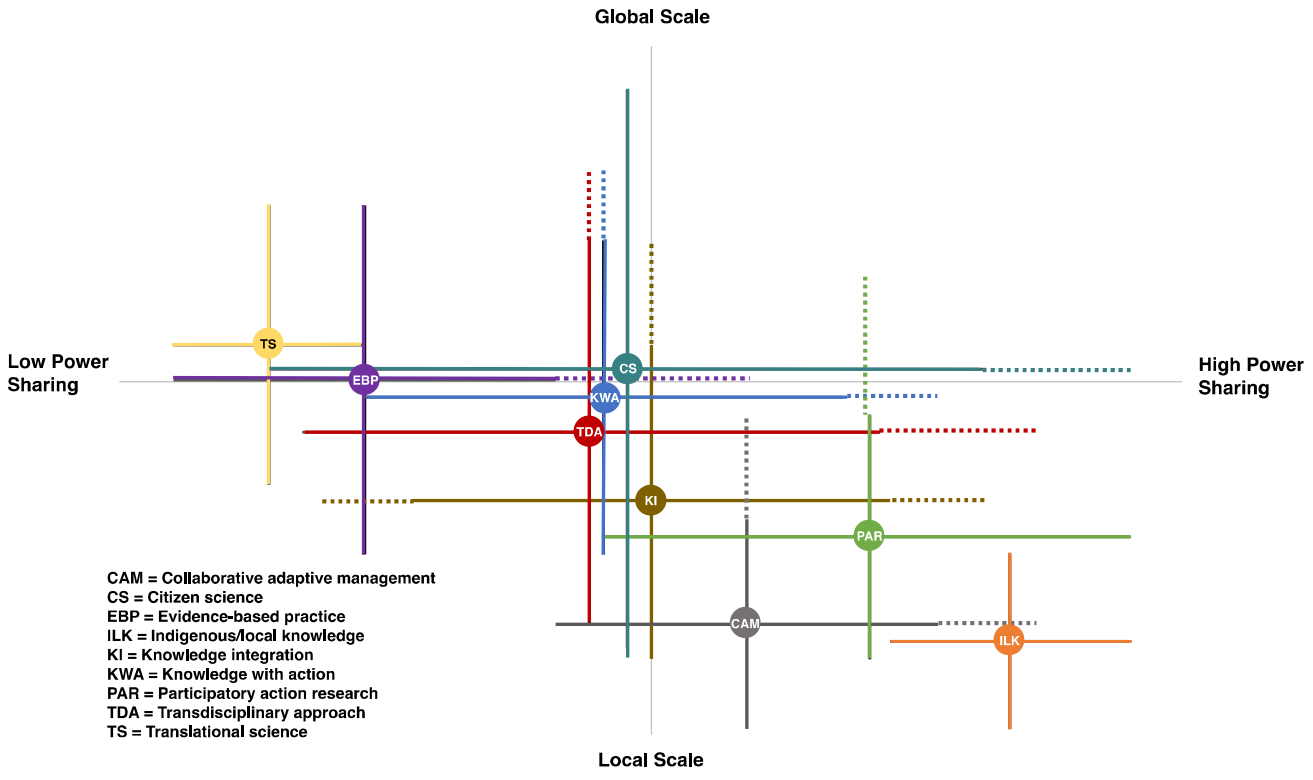

Figure 3. Reviewed approaches compared by scale of application and level of power sharing. Circle in center shows primary position of each approach while solid lines show current range and dotted lines show anticipated direction of movement. 


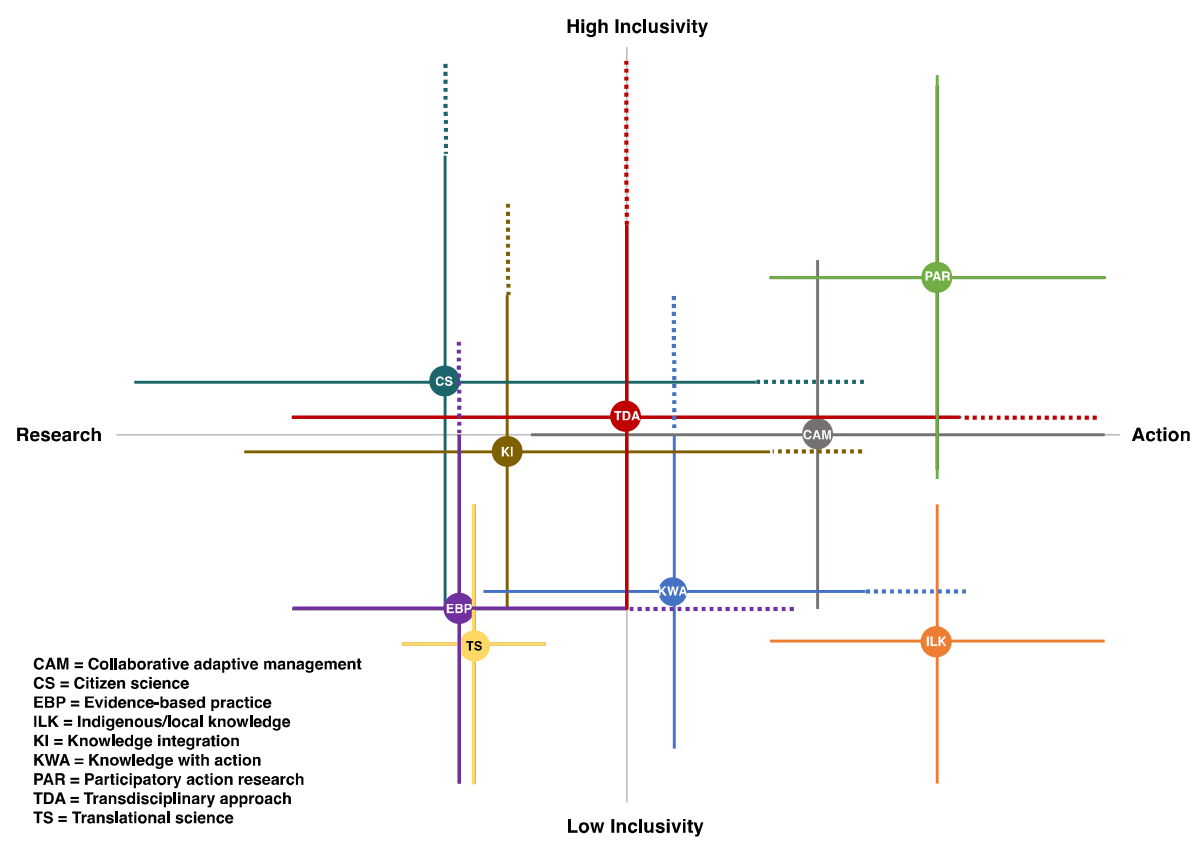

Figure 4. Reviewed approaches compared by primary goal (research or action) and level of inclusivity within the approach to knowledge production. Circle in center shows primary position of each approach while solid lines show current range and dotted lines show anticipated direction of movement.

\section{Results: Literature Review}

\subsection{Indigenous/Local Knowledge}

Indigenous/local knowledge (ILK) asserts that there is no single origin for knowledge, and that systematic ways of interacting and understanding the world have emerged in different cultures and have different practices and methods [27-30]. ILK systems have been around since the evolution of our species and have developed different forms in heterogenous contexts. In this paper, we recognize a range of ILK including indigenous science, indigenous knowledge, traditional ecological knowledge and local knowledge. These ways of knowing differ based on their cultural connection and mode of acquisition, which include traditional (passed across generations), empirical (based on careful observation and practice), revealed (obtained through vision, ritual and ceremony) and contemporary (experience, education and problem solving) [31]. ILK can also be described as a high-context view that attempts to understand relationships instead of reducing context [32]. While these systems of knowing have some elements in common (e.g., holistic, relational), they are also as diverse as the people and contexts in which they arise [31]. ILK is developed and utilized in order to adapt, survive and thrive in place [33], and thus its utility and value is based on its applicability.

One type of ILK is "indigenous science", defined as an alternative to scientific traditions rooted in renaissance/enlightenment thinking and typically described as modern science, and emerged as a response to educational and research institutions that failed to recognize alternative ways of knowing [28], researchers who failed to respect different knowledge systems [34], and conservation that failed to integrate native worldviews [35]. Indigenous science treats nature as an alive and active partner in the research process [36]. The goal of indigenous science is to maintain balance with the natural world. It does this through drawing on all forms of human experience (observation, traditions, spiritual, etc.) and collapsing time and space to understand patterns across these dimensions [28,37]. It also places a value on the embeddedness of the perceiver and their role in the research process. Instead of a specific set of methods, indigenous science is a systematic, ethical and integrated approach for understanding the world. Some have argued that many environmental disasters were caused by 
reliance on modern science, and therefore it is critical to teach indigenous science alongside modern science [33,38].

\subsection{Participatory Action Research}

Participatory Action Research (PAR) is one of the oldest approaches to connecting people who produce knowledge and apply it. It engages researchers as partners in research design, implementation, and interpretation, and holds awareness raising and action as goals co-equal with knowledge co-production. Rooted in the work of social psychologist Kurt Lewin (1948) in the US and educator Paolo Freire (1970) in Brazil, PAR evolved in various directions, influencing Participatory Rural Appraisal (PRA) in international rural development [39], community-based research (CBR), and participatory research (PR). The health sciences [40] and education have applied PAR since the 1970s, and PAR increased in popularity in natural resource management since the 1990s [41-43].

PAR methods include both conventional social science and humanities research tools like surveys and interviews, and innovative participatory approaches, such as photo-voice, participatory videography (e.g., [44]) and arts-based methods like participatory theater [45] and poetry. PAR has demonstrated important outcomes, especially in health sciences and education, where it has the longest history. Such outcomes include more effective public health campaigns [46] and greater visibility and policy attention to environmental racism [47]. In natural resource arenas, PAR has included voices of marginalized populations in natural resource planning and decision-making [48], strengthened social capital [41] and built community capacity [43]. This approach has typically been used by natural resource social scientists, with little application from biophysical scientists [49]. From the perspective of community members, an important outcome is the recognition and inclusion of their knowledge as important and useful, an indicator of altered (if not inverted) power relations [43].

PAR aspires to reverse the power relations between researchers and communities [40,48], by asking community partners to define research questions and objectives related to their goals, and asking scholars to support those goals. The aim of power sharing through PAR remains elusive, however. Major critiques of the approach show how participatory rural appraisal (PRA) may reinforce rather than invert existing power dynamics in the international development arena (e.g., [50]). Reviews consistently discuss the challenges or "entanglements" of power; both power-sharing between academic and community research partners, and navigating power dynamics within communities [48,51,52]. Due to the community-based nature of most PAR, the unique context of each community, and PAR's dependence on strong relationships of trust and reciprocity between researchers and community-members, PAR is also challenging to "scale out" across multiple sites/communities within a single initiative.

\subsection{Knowledge with Action}

Knowledge with action (KWA) grew out of policy and sustainability science, recognizing complex interlinked problems and the need for solutions-driven knowledge [53,54]. Typical knowledge production operates under the assumption that significant findings in research will result in public interest and subsequent action [55]. The researcher's responsibility is to publish scientific articles in peer-reviewed journals. Though this may be adequate in certain disciplines and for certain subjects, it has proven ineffective in contexts meant to address sustainability, sustainable development and most recently, conservation. The 1970s showed movement towards "research utilization", aiming to connect research findings to changes in social policy [56]. This model relied on active translation of the research to influence public awareness and understanding rather than simple, passive release of information. However, this model has led to implementation issues, such as when research is turned into policy without getting the public or practitioners on board, as seen in the fields of agriculture and health [55]. Another example is the assumed linkage between social science and political decision-making. The theory of the rational decision-making process, based on positivist and rationalist concepts of the use of science are idealistic and therefore unrealistic [57]. Ineffective political negotiation surrounding climate change policy is an example. 
KWA requires fundamentally new connections among different ways of understanding the world $[58,59]$. The term has also been known as knowledge to action, but this term suggests a one-way direction of research use and does not communicate the two-way relations of co-production and collaboration to the crafting of usable knowledge that is relevant in local contexts. KWA has produced several frameworks demonstrating how to address complex problems (e.g., [9]). All frameworks agree that 'knowledge with action' is problem-focused rather than discipline-focused, has an evolving methodology and collaboration [58-60], and most often involves non-academic actors [61]. However, the frameworks tend to focus on the research steps and not the realities of the complex human-environment systems within which problems reside. Scholars (e.g., [62]) suggest the need to be cognizant of interactions among a system's component parts and the likelihood of unintended consequences at multiple scales, and the political and power dynamics of the work [53]. For example, users must trust the researchers so that the work will be perceived as credible by users, be salient to their needs, and be seen as legitimate to users $[53,63,64]$. Thus, although the approach can be used globally, it must be adjusted to local conditions.

KWA methods are constructed around co-production of knowledge in the design and framing of research, the integration of research results and knowledge dissemination. At its best, the approach is made up of agents, practices and institutions that organize the production, transfer and use of knowledge [9]. Most KWA frameworks see sustainability as an outcome of social learning where compromises or tradeoffs are being sought to achieve multiple social, economic and environmental outcomes. Collaborations bring issues of power to light directly so that collaborators are forced to look at how power is used, expressed and practiced [65]. This joint process is proposed to lead to a better understanding of the types of outputs useful for policy and action. They are best presented in a format that uses understandable language, and at a scale useful for decision-making [66]. Recently, Future Earth created a structure for facilitating continuous networks for knowledge with action.

\subsection{Knowledge Integration}

The knowledge integration (KI) approach is distinct from ILK in its focus on integrating different knowledges, specifically ILK (described above) and modern scientific knowledge, to gain a more complete understanding of reality. The first peer reviewed publications using these terms emerged in the late 1970s, although documentation of different ways of knowing are common in cultural ethnographies arising in anthropology, early natural historians who used their own careful observations to build theories about the world, and conversations between emerging "researchers" (ecologists, biologists) and those who have practical and experiential knowledge [30]. This field was influenced by the Structure of Scientific Revolutions [67], which increased awareness of the social processes of modern science and questioned its superiority, and the growth of Science and Technology Studies (STS), as well as increased interest and acknowledgement of other ways of knowing [68,69]. Simultaneously, increased awareness of the need to understand linked social-ecological systems led to consideration of what other knowledge systems could contribute and how they might adjudicate debates in the modern scientific literature $[30,70]$.

A wide variety of natural-resource-related fields from agriculture [71] to ecology [30] use knowledge integration to better understand natural systems. Although some have argued that modern scientific and experiential knowledge differ [72,73], most knowledge is hybrid [74-76]. While ecological and conservation-focused studies that integrate experiential knowledge increased during the 1990s and early 2000s, they often treated knowledge as a set of facts that could be extracted rather than involving local knowledge holders as collaborators [77]. Knowledge integration processes have also often required conformation to modern science by testing or evaluating experiential knowledge claims against those obtained through the scientific process, instead of respecting and acknowledging its unique epistemology [78,79].

There are a variety of integration approaches that vary in underlying assumptions and goals. In 1997, Blaike suggested five types of approaches, including: appropriation, functional, intrinsic, 
negotiated and empowered [80]. In this typology, the first two treat knowledge as facts that can be extracted, while the second three acknowledge more of the complexities of knowledge production and transmission. More recently, Tengö and colleagues suggested five approaches to engaging local knowledge systems (not just knowledge) to enhance global sustainability. These are to mobilize, translate, negotiate, synthesize and apply [81]. Methods of knowledge integration include collection of knowledge claims through interviews, participant observation and ethnographic studies, collaborative fieldwork where participants co-produce knowledge, modeling that uses both local and social and ecological information, workshops with diverse knowledge holders, and other tools such as photo-voice and participatory mapping (e.g., [82]).

Knowledge integration outcomes include quantitative or conceptual models of systems, syntheses, and new questions about the system. This approach can lead to more awareness and respect for other ways of knowing, or can strengthen existing hierarchies by using scientific knowledge to validate experiential knowledge [83]. Critiques include removing knowledge from its social and political contexts, and therefore overlooking issues of power and privilege [74,84], failing to incorporate knowledge systems or epistemologies [85], and lack of attention to issues of process (e.g., [86]). This approach has moved the consideration of knowledge-integration products to the careful design of knowledge-integration or knowledge bridging processes [87], including co-science and coproduction of knowledge [59], dialogic networks [88], the Multiple Evidence Base (MEB) approach [89], and knowledge exchange [90]. These approaches move beyond integration of facts to recognize and respect traditional ways of knowing, the rights of individuals to help structure the bridging process, and the importance of harnessing multiple types of knowledge for real-world problem solving.

\subsection{Translational Science}

In the 1990s, medicine had a problem: medical research no longer reached patients' bedsides. Translational science (TS) was born to meet patient needs. By the 2000s, TS delivered 'bench to bedside' medical research, with its own journal, major funding and awards [91]. In 2010, ecologists adapted this approach for ecological research [92], with less emphasis on 'clients', dubbing it 'translational ecology'. In this approach, 'ecologists, stakeholders, and decision makers work collaboratively to develop ecological research via joint consideration of the sociological, ecological, and political contexts of an environmental problem that ideally results in improved environment-related decision making' [93].

TS today appears in medicine, ecology and climate science [94], with all of these disciplines emphasizing the goal of involving end-users in the research process. The word 'translation' implies a need for the parties involved to make their languages mutually intelligible, and understand each other's cultural views. While medical applications focus on bringing together different disciplinary experts, translational ecology focuses on the process of bringing ecological scientists and stakeholders together, using principles of collaboration, engagement, co-production, commitment, communication, process, and decision-framing [93]. TS emphasizes mutual learning between scientists and stakeholders; here, knowledge co-production is helpful but not required for successful translation (e.g., [93,94]).

At its best, TS in medicine can hasten the development of breakthrough impact on major new cures for globally important diseases. TS in ecology rarely has this level of impact, likely because of the place-based nature of environmental issues. Translational ecology projects focus on incrementally improving decision-making on critical environmental issues. All TS practitioners claim that the process leads to more enduring impacts $[93,94]$. At the same time, scholars recognize the challenges of translational work, which include the different incentives in the worlds of modern science and practice, the additional time needed to do this work and its potential for conflict $[93,94]$.

\subsection{Evidence-Based Practice}

Evidence-based practice (EBP) developed parallel to translational science within the health field, but with a focus on synthesizing large bodies of primary research to reduce bias and increase integration 
with practice. Its goal was to increase the rate at which medical discoveries were used in practice and increase the delivery of health care to patients [95]. This movement started in clinical medicine but spread to nursing, psychology, social work and public health. While originally relying primarily on systematic reviews, EBP expanded to multi-disciplinary approaches which "moved from silos to synergy in interdisciplinary EBP' [96], causing a paradigm shift in medicine. EBP challenged disciplinary approaches and power dynamics, the former between disciplines and the latter called the 'most advanced level', where scientists and other stakeholders engage with each other. Challenges remain, however, with respect to how 'evidence' should be defined, how contextual factors should enter the clinical decision-making process, what is the role of the 'expert' and what other variables should be included in EBP including social class and local expertise [95].

In the early 2000s, Pullin and Knight [97,98], borrowing from the health field, suggested that the problems of environmental change and biodiversity could be better addressed by use of systematic evaluation of evidence to gauge the effectiveness of environmental managers' actions. They made the case that environmental management must demonstrate that practices are beneficial, effective, and cost efficient. The speed of knowledge generation should also correspond with political processes so policy and decision-makers can access appropriate information in a time-sensitive manner [66]. To speed up the use of information, Walsh et al. (2015) claimed that brief research synopses to conservation managers increase their likelihood to change management decisions rather than rely on experience or opinion as they had in the past [99].

The Collaboration for Environmental Evidence (CEE) was created in 2007 to facilitate the creation of systematic evaluations and research syntheses for environmental conservation. Their journal Environmental Evidence is an open-source hub for the publication of such reviews, focusing on the results of conservation initiatives and synthesis methods. Numerous systematic reviews have been published with the intention of informing policy-makers and conservationists to improve conservation interventions. In addition, groups like Science for Nature and People Partnership (SNAPP), the National Socio-Environmental Synthesis Center (SESYNC) and non-profits like the Nature Conservancy have adopted this approach. However, actual applications of evidence-based conservation remain scarce, as much of the published research is presented without conservation action [100], because researchers never planned for implementation of their findings. Closing this "implementation gap" is critical for effective evidence-based environmental management in the future [101].

\subsection{Citizen Science}

Even though Irwin and Bonney coined the term 'citizen science' (CS) only two decades ago [102,103], non-scientists have been collecting scientific data for more than a century [104], and probably millennia. Citizen science is unique in its diversity of scales, its naming of participants as scientists, and its (often) online nature. Today, scholars and practitioners (primarily in Europe) define citizen science as the philosophy of engaging the public in scientific discourse and policy making [103]. In the US, citizen science is defined as the process and practice of non-scientists collaborating with professional scientists to collect, transcribe, categorize and/or analyze data $[104,105]$ 'that contributes to our understanding or management of the natural world' [106]. Citizen science falls under the broader rubric of 'public participation in science', which also includes volunteer or community-based monitoring [107], community science [108], and overlaps with participatory action research [104,109].

Goals of citizen science projects vary from large dataset collection to public education [110]. In crowd-sourced projects, citizen scientists around the world may work on pattern recognition of data online, like galaxies [111], with no connection to their particular location. In projects that aim to collect broad, high quality datasets across regions or even nations (e.g., [112]), citizen scientists are place-based data collectors, linked only by a larger, far away project that they see online. Other projects focus first on education [113], with the quality of data collection sometimes secondary. Some projects are small and work on specific local issues, often led by citizens who generate local datasets [107], while other 
projects explicitly cross scales by collecting place-based data, and integrating this information into a much larger scale dataset.

There are multiple models of citizen science $[104,109]$ that differ by who determines the scientific problem to be addressed and who leads the initiative. In a contributory model, scientists lead the projects and citizen-scientists collect and contribute data and samples. When scientists and citizen-scientists work in a collaboratory model, they define shared research goals and collect and analyze data together. Leadership shifts over to citizens in the co-creation and collegial models, in which either citizens develop a study and work with input from scientists (former), or they work entirely independently without scientists (latter). Sometimes the last model evolves into citizens determining the problem but contracting scientists to do the work and report back.

The outcomes and impacts of citizen science vary by goal and scale. Many large-scale efforts create unprecedented, real-time datasets of changing phenomena, while others create small-scale datasets that generate local understanding or foster ecological literacy. They can also contribute to more transformative outcomes, including influencing future research, policy, and education directions of natural history museums [106]. Experience with citizen science projects can cause citizens to understand and support modern science more generally [105]. Citizens often feel empowered by participation, and can subsequently choose to participate in other leadership activities. These outcomes currently have limits, with more progress needed on transformative learning at the organizational level to promote larger impacts on policy and scientific practice [113].

Scholars of citizen science, while recognizing its strengths, think this approach to science has not reached its full transformative potential. While some citizen science projects collect data over wide areas in standard ways, there are also many disconnected small-scale datasets on similar subjects collected with different methods. Citizen scientists could also be collecting social data and information about social outcomes. Participants are currently not diverse enough. Many scholars call for better evaluation of what participants have learned, whether participation influences behavior, and whether projects affect decision making and application [107]. More broadly, several scholars see a major unrealized potential: full transformation of science itself, scientific institutions, and the larger relationship of science and society $[113,114]$. In addition, as with all endeavors, this transformative potential cannot be reached unless there is more financial investment in these kinds of projects [115].

\subsection{Collaborative Adaptive Management}

Collaborative adaptive management (CAM) is unique in its focus on collaborative decision making between scientists, stakeholders, and managers. It reflects a shift from command and control of natural resources towards community-based management [116,117], and the integration of modern science and management via formal adaptive management (AM), defined as the application of experimental design to implementation of resource management to speed learning and reduce uncertainty [118]. CAM originated on US public lands and brings together multiple stakeholders to employ a structured, deliberative, and iterative decision-making process to assess the system, define goals, design experiments and monitoring, evaluate monitoring, re-visit assumptions, and alter management to achieve goals. Adaptive co-management $[118,119]$ and adaptive collaborative management [120] share many features and benefits with CAM, but have a greater emphasis on power sharing and knowledge integration through co-management. We draw from all these literatures, but focus on CAM because of its explicit emphasis on and origins in blending science and management to solve natural resource problems.

Proposed CAM benefits include both those of adaptive management including more rapid and reliable learning that decreases ecological uncertainty and increases management effectiveness [121], and benefits associated with collaboration, such as incorporation of a wider range of knowledge and perspectives leading to potentially novel solutions [122,123]; increased trust, stronger relationships and decreased conflict (i.e., greater social capital); integration of monitoring into management decisions; greater social acceptance of management decisions; and potential for learning to diffuse through the 
broader community [124-126]. CAM is also associated with claims for multiple-loop learning, that is, learning beyond simple cause and effect (single loop) to changes in system assumptions (double-loop learning), and the values, norms or institutions that support them (triple-loop learning) [124,126].

CAM faces implementation challenges stemming from technical and institutional constraints [127129] and social dynamics. Social challenges include failure to involve the right stakeholders or insufficient involvement by participating stakeholders, lack of continuity in participants, insufficient facilitation, and failure to monitor social learning [130]. Rist et al. (2013) claimed that the social and ecological aspects of CAM must be separated for success to occur [131], while Fernandez-Gimenez et al. (2019) argue that social learning emerges from the complex social-ecological dynamics of CAM [132]. Many challenges likely arise from lack of awareness and attention to power dynamics among stakeholders, including agencies and researchers, and missed opportunities for reflexivity.

Despite these challenges, several published accounts describe successful and long-running CAM processes that demonstrate the achievement of many benefits $[124,126,133]$. Evidence is strongest for the social benefits of CAM, especially those related to social capital and social learning, and for an association between stakeholder participation and implementation of management based on CAM monitoring and decision-making. The ecological outcomes of CAM are less well documented, and only one study, still in its early phases, directly compares ecological outcomes of CAM with conventional management [126].

\section{Results: Exploring Interactions}

This review demonstrates that there is a long history of sub-currents within modern science that have worked to create knowledge that is relevant, credible, legitimate and applied. The approaches included in this review developed in tandem (most starting in the mid-1990s) and their representation in the published literature has increased over time (Figure 1). The earliest to develop were indigenous/local knowledge and participatory action research, and the most recent to develop were translational science and collaborative adaptive management. The citation history shows that TDA is relatively new, and less common than other approaches. Given the long history of practice and application of certain approaches, practitioners of collaborative approaches may benefit from greater dialogue and synergy.

There are different trends in each collaborative approach. While the number of papers published for some approaches continues to increase each year (e.g., citizen science), others seem to have plateaued (e.g., translational science). Regardless of the individual patterns, it is interesting that in the past ten years, these approaches have coexisted and increased in tandem. The author team's knowledge of these literatures suggests little overlap between these reviewed approaches and TDA. Since TDA developed and grew in the mid-2000s, it could benefit from understanding alternative approaches with longer histories.

Each approach developed from a different discipline in a different time period (Figure 2). As the timeline shows, these approaches often arose in fields where application is critical (health, natural resource management, education), and most approaches have expanded to other applied fields over time. It is possible that further exploration would show that additional applied fields (e.g., engineering, planning, architecture) have similar trends that we did not capture due to our focus on approaches that have influenced conservation and natural resources. In Figure 2, the order of disciplines shows how approaches expanded across disciplines over time, but does not imply that earlier disciplines stopped using these approaches. Given our interest in conservation and natural resources, it is not surprising that we focused on approaches that led to contributions in these fields.

We were also interested in how these approaches compare with each other based on degree of power sharing and geographic scale (Figure 3), and the degree of inclusivity and relative focus on research versus action (Figure 4). We considered each approach's current range related to each dimension as well as where the literature and our knowledge of each approach suggest they are going in the future. Power sharing relates to how power is shared between researchers and stakeholders. Geographic scale relates to the typical range of spatial scales for a given approach. When comparing 
power sharing to scale (Figure 3), we see that local scale is associated with high power sharing and broader scales with lower power sharing. Most reviewed approaches are local to regional in scale. When we consider the aspirations of each approach, it is evident that most wish to share more power, and several are extending towards larger scales.

Inclusivity relates to whether each approach includes different types of stakeholders, as well as how intensively they include them throughout the project. Relative focus on research and action relates to the emphasis put on each dimension. When comparing degree of inclusivity with relative focus on research vs action, we find a less distinct pattern, with several approaches encompassing a large amount of the overall domain (Figure 4). Approaches that are more centered between these poles seem to have a larger amount of variation. Interestingly, TDA is in the center of this figure, suggesting that it encompasses much of the range of prior and contemporary approaches. This means that application of this approach is diverse, and lessons from the other approaches might be informative. Most of the approaches seem to be moving towards higher inclusivity and increased focus on action.

These approaches have various goals, including: better communication and integration into decision making (EBS, TS), engaging stakeholders for better and more efficient science (CS, KI), presenting other ways of knowing (KI, ILK), problem-solving with communities (PAR, ILK) or informing management decision-making (CAM). In addition, all approaches want to learn about complex knowledge-action arenas. Their focus on application has led each to ask about the process and players in modern science, and how players and process need to shift. Each has answered these questions differently, reflecting their goals, field, and area of application, but they suggest several meta-themes.

\section{Discussion}

\subsection{Meta-Themes across Approaches}

\subsubsection{Attention to Social Processes of Knowledge Production}

The collaborative approaches reviewed in this paper encompass social as well as scientific processes, and while lessons have been identified in TDA about social processes [134], TDA can lack attention to how knowledge is produced and the importance of social dimensions [9,23]. Clark et al. (2016) argues that to manage sustainability issues, researchers must shift from knowing to learning, requiring a methodological and philosophical shift [53]. Since the problem arenas addressed by these approaches are often dynamic and complex, they frequently focus on the process of learning rather than knowledge outcomes. Learning is a social process, which requires attention to levels of engagement, sequencing of activities, and communication. It would be useful for TDA practitioners, and others working at the intersection of research and practice, to reflect on prior approaches to bridge scholarship and society to learn about effective practices.

The reviewed approaches all engage the public in different ways including as designers (PAR), collaborators (CAM), knowledge holders (KI), knowledge creators (IS), and data collectors (CS). In CAM and PAR, scientists work alongside communities to act and learn from that action in an iterative process. In these literatures, there is a long history of scholarship around social learning $[109,135,136]$. Even in approaches that are more unidirectional, participants understand the need to learn from the process of sharing information (TS, EBS). However, within each approach there are a range of ways that the public can participate in the research process from collegial to contractual [109]. It may be useful to explore when different engagement approaches emerge and whether these are determined by context, project limitations, preferences, training, and/or capacity. For instance, CAM practitioners have developed best practices about engagement [121] while CS leaders have learned about volunteer motivation [111,137] and engagement [138].

While some approaches have started to develop guides and best process practices, documenting the sequence, activities and practices of knowledge production is not typical (but see Thorn et al., in review). Critiques about the lack of documentation and assessment of process, including steps or 
stages of engagement, strategies for facilitating learning and interactions across diverse backgrounds and ways of knowing, and practices for decision-making, power sharing, and conflict management have emerged across these literatures. Documentation and assessment of process would allow different efforts to learn from one another [87,139]. For instance, there has been a lack of attention to the process of knowledge exchange [90]. Other literatures emerging from alternative environmental dispute resolution [122] and communication in team science [140] may provide guidelines for process design and implementation to facilitate collaboration across diverse epistemologies. The long history of practice embodied in these approaches might suggest guidelines about how to develop useable knowledge that differs from and expands upon the scientific method.

As might be expected, these approaches pay attention to communication, both within the project team and outside it. Since the goal of many of them is to inform action, they need to plan for effective methods of communication within the research/practice team, and with decision-makers, key stakeholders and the public. Many approaches discuss the importance of building trust for desired outcomes (e.g., [93]). While some are primarily focused on communication of completed research (TS) or synthesis of evidence for practice (EBS), others must integrate careful and thorough multi-directional (i.e., not uni-directional) communication throughout the processes of learning (PAR, CAM). Typical forms of scientific communication (conference talks, peer-reviewed literature) are not adequate, and often more direct, interactional and innovative approaches are needed. Attention to and synthesis of lessons learned about social process could help to inform the practice of TDA, as well as broader awareness of the literature of communication studies, alternative dispute resolution, science communication, team communication, and social learning.

\subsubsection{Recognizing Different Ways of Knowing}

Scholars identified integration of different ways of knowing and types of knowledge as one of the main challenges of TDA [141], and identified a corresponding number of research questions about integration [5]. Collaborative approaches have wrestled with these questions over time. At one end, ILK presents ways of knowing that are alternatives to modern science. Other approaches value the diverse perspectives that stakeholders can bring to applied contexts, from defining and exploring local issues of concern (PAR), working together in a learning process (CAM), bringing lay people into scientific research (CS) and integrating different forms of knowledge for the understanding of a subject area (KI). These approaches also question the types of knowledge that need to be considered in a project, from policy knowledge (KWA) to practitioner knowledge (EBS). In these approaches, we see that integration of different forms of knowing can lead to more holistic understanding of contexts, better information and awareness of the problem areas, and community ownership of resulting knowledge, which may lead to empowerment of disempowered voices and effective application and implementation of knowledge. These approaches all acknowledge and understand the potential of different ways of knowing to assist in the management of problem arenas. Attention to how these approaches integrate different forms of knowledge may make decisions TDA researchers face more explicit and grounded in prior experience.

Despite the broadening of science in terms of whose knowledge is included, we still see that most consider modern science primary. Modern science has often been used as the measuring stick for gauging validity of other knowledge claims (KI), provides the methods that citizen scientists adopt (CS), and is the primary content that needs to be communicated (EBS, TS). Even in more integrated approaches, modern science often provides the scaffolding for community participation (CAM, PAR). The approaches reviewed here are typically led by someone trained in modern science. Given TDA's commitment to creating science to lead to system transformation, it is important to question assumptions about the primacy of modern science. Early TDA thinking suggested a broader and somewhat revolutionary approach to knowledge production, with an opening for increased dialogue between different ways of knowing such as science and mysticism [142]. Rethinking who 
leads projects and how knowledge is integrated may lead to more applied and impactful project outcomes, by addressing underlying power issues

\subsubsection{Considerations of Power}

A recent review of TDA projects has shown that empowerment is rare across case studies, and few TDA projects pursue full engagement of all stakeholders at each stage in the process [4]. Given the increased funding for and use of TDA, it is critical that TDA projects consider power so that the outcomes are equitable and truly serve sustainable development goals [4]. Power differentials can exist between disciplines, and between scientists and non-scientists, stakeholders, and communities, and it is important to acknowledge them.

The approaches in this review vary in their consideration and integration of issues of power, from those that have explicitly integrated it (PAR), those that have seen increased attention and critique in how they integrate it (KI, CS), those that have explored different models of power-sharing (CAM) and those that promote and highlight alternative systems of knowing (ILK). By bringing stakeholders into the process of knowledge creation, these approaches highlight how certain ways of knowing are privileged over others, who gets to make the decisions embedded in the modern scientific process, and what types of questions are pursued within modern science and scholarship.

The level of power sharing appears connected with the relative emphasis on action, with approaches that focus on action also paying more attention to power (Figure 3). In each of these approaches, there have been critiques that call for a better integration of these issues [4,25]. One specific call has been for designing processes that help to deemphasize and navigate differences in status and power between project partners [143]. Approaches such as PAR provide a more intensive learning cycle and build adaptive capacity [144]. Attention to both what has (and has not) worked in prior approaches may help TDA researchers to incorporate best practices and avoid pitfalls.

Extending beyond these collaborative approaches, TDA may also benefit from greater engagement with critical theory, including branches of feminist, decolonial and Marxist theory, which help to understand the history of unequal power and its connections to the creation and use of knowledge. Feminist theory could provide awareness of intersectionality, or the systems of power that shape human society and experience [145], how identity influences outlook (positionality), and how different types of knowledge are valued based on power [146]. Decolonial theory could assist TDA researchers to understand how colonial history shapes modern structures of power [147] and how Western European ways of knowing, such as modern science, are not universal or higher ways of knowing [148]. Critical theorists such as Habermas could help researchers consider how different ways of knowing lead (or fail to lead) to action, and the traits of critical knowledge (such as self-reflection) that may lead to shifts in power structures [149].

\subsubsection{Navigating Complexity and Reconsidering the Value of Generalization}

The need to navigate real-world contexts and iterate between abstract and concrete knowledge is a methodological challenge for TDA [17]. By exploring complex real-world problem arenas, these approaches all work to navigate complexity in different ways than modern science. Instead of limiting variables of interest and controlling external factors, these approaches often launch themselves in specific and dynamic contexts. A recent paper has suggested that TDA projects use arguments by analogy to facilitate cross-project learning, but these approaches are just being formulated and tested [26]. Many of the approaches in this review embrace complexity and, in this embrace, shift the understanding of the purposes and outcomes of science.

The reviewed approaches have slightly different approaches for dealing with generalizability. For several approaches, they focus on learning by doing and working with the people who are most interested in and affected by the resulting knowledge in specific contexts (CAM, PAR). Citizen science is varied, with some projects using complex models of data collection by diverse data collectors to achieve outcomes that are generalizable; other projects focus on local contexts and then compare 
across the site specificity to reach larger scale generalities. Several approaches, since they focus on application, are more concerned with contextualizing generalizable knowledge so that it can be applied in specific contexts (EBS, TS, KA). Each of the approaches reviewed in this paper push what and how we should think about generalizability. Some of these approaches focus on problem-solving in specific contexts and question whether generalizability should be the goal, since the need is localized (CAM, PAR). Others (CS) question how generalization might happen with larger and more diverse data sets. Still others (EBS, TS) help to re-contextualize generalizable information by making it more focused on local context and application.

While many of these approaches seek more use-inspired, applied and relevant knowledge for action, research funders often desire the production of generalizable knowledge or application on larger scales. There are applied and action-oriented funders that differ in their criteria for success (e.g., the Bill and Melinda Gates Foundation and the Ford Foundation). This creates tension among these approaches, as it is not possible to do everything equally well. Since approaches that work at a local scale often require relationship building and knowledge of context, it would be a challenge to both invest in local community-scale efforts as well as making larger policy-relevant suggestions. One solution could include nested learning networks to address the issue of scale in outcomes and policies [150]. TDA researchers and funders should engage in a broader discussion of the best scale for learning and application, based on specific project goals, and informed by approaches included in this review.

\subsection{Implications of Understanding TDA Antecedents}

\subsubsection{Expanded Roles for Knowledge Production}

The approaches reviewed in this paper suggest a new relationship between science and society, but the implications of this relationship are not sufficiently understood [141]. This shift has implications for roles of typical players (scientists, stakeholders), as well as a potential new role, that of boundary-spanning pracademic, whose role is to bridge different ways of knowing, research/practice, multiple disciplines and institutions, etc. (e.g., [151]). There is growing recognition of the importance of this role in more applied academic settings, from public administration to health and criminal justice [152]. While scientists still need to be knowledge experts, they also need to be co-learners who straddle knowledge domains and learn with communities [134]. If researchers take the challenges of sustainability seriously, they will need to engage with problems and the ways to navigate and resolve them [92]. This will require changes in training of future sustainability leaders (see Section 5.2.2). Stakeholders need to rethink what types of knowledge are most useful for effective decision-making, which processes are most likely to produce them, and then communicate these needs to researchers. Stakeholders also need to engage in meaningful and often time-consuming ways to foster local understanding of scientists and pracademics.

\subsubsection{Training the Next Generation}

Acknowledging these expanded roles influences how we train the next generation of leaders (both academic, practitioner, and pracademic) [53]. Because these approaches are highly labor intensive and involve tension/conflict, next-generation leaders must possess "collaborative readiness", which requires preparation, practice and continual refinement [143]. Future sustainability leaders will need to understand how to navigate complex systems, manage conflict, communicate with diverse stakeholders, assess situations and analyze stakeholder dynamics, design inclusive processes, recognize power differentials and seek to rebalance them, and create effective learning processes. These are not the typical skills of technically trained natural resource managers of the past. They will require new approaches to training and education that allow for practicing these skills, applying knowledge to real-world contexts, and adding content to existing curriculum. These skills will benefit a range of students, regardless of their career trajectories. Future academics will learn a more engaged and active 
process for conducting research, practitioners will understand where and how to work with academics to inform decisions, and pracademics will gain experience navigating these intersections.

\subsubsection{Incentive Systems}

Individuals within academic institutions, non-profit organizations and federal agencies all respond and work within existing incentive structures. Incentive structures include financial incentives, but also criteria for evaluation, prestige, community recognition, and opportunities for advancement. Although grants for TDA approaches are increasing (e.g., www.belmontforum), this approach to knowledge production often does not fit well within traditional funding mechanisms, which are focused on short-term funding cycles and lack of resources for relationship investment [141]. Given the time-intensive and trust-building elements of many of these approaches, they require unique funding mechanisms, including seed funds to explore and design projects with stakeholders, multi-year funding to make progress, and funding for both formative and summative project evaluation, as well as documentation of long-term outcomes. There is also a need to fund synthesis and cross approach learning to address some of the intersections between the reviewed approaches.

Criteria for tenure and promotion evaluation could shift by valuing collaborative contributions. There is a need to better conceptualize of how scientific discovery, community practice, and coordination of evidence-based policies and programs all fit together [143]. If academics were evaluated equally based on different types of impact (on policy, partners, real world problem solving) as well as on traditional metrics such as publications and citations, we would likely see more applied and useful research. However, the evaluation of these diverse types of impacts is critical to this shift in these criteria for success in academia. Trends towards encouraging and incentivizing engaged scholarship are on the rise [153]. Opportunities to celebrate science-stakeholder partnerships and build the support and recognition for them would also be beneficial. Although land grant institutions often include an outreach and engagement component in faculty workloads, this is often focused more on communicating the outcomes of research rather than the more time-consuming partnership with community stakeholders. Including these novel partnerships in evaluation and promotion would be a benefit for encouraging more of these approaches on the ground, as would institutionalizing these practices in centers, educational programs, or funding opportunities.

\subsubsection{Implications for the Practice of Transdisciplinarity}

TDA could benefit from these approaches by including more explicit consideration of power, being more explicit about decisions regarding scale and generalizability (CS vs. KWA), learning from how other approaches have integrated different forms of knowledge, and more articulated consideration of social processes of knowledge production. A realistic and transparent assessment and navigation of power differentials should be a part of TDA. While all reviewed approaches struggle to some extent, PAR, CAM and ILK have progressed further in terms self-critique, navigation of power, and designing processes that better integrate issues of power. It would be useful to synthesize best practices from these approaches. Collaborative approaches could offer suggestions about how to both work at multiple scales: methods from CS could be used to scale up explorations of ILK, the systematic reviews of EBS could compile lessons learned across case studies, CAM could catalyze conversations about learning and sharing of knowledge across scales, and PAR could illustrate what is lost when scaling up occurs. These approaches have wrestled with how to integrate different types of knowledge. Lessons from KI could highlight the challenges and opportunities of integration, while ILK could reveal other knowledge systems and their metrics for validity. Finally, social processes of knowledge production are important to understand. By synthesizing lessons learned about engagement, sequencing, and communication from these disparate approaches we might better articulate what processes are best in which contexts and how they can lead to both different knowledge and levels of application of that knowledge. 


\section{Conclusions}

In the inter-space where these collaborative approaches converge, we see that they often overlap with modern science, but are also broader. The roots of these approaches tap into values, culture, and collective action, stretching and challenging what science has typically been. We can see this in the focus on learning in CAM, the aim of collective action in PAR, and the desire for policy influence in KA. These issues are pushing the envelope of what modern science is, and creating forms of knowledge production at the border of scholarship and practice. In the intersection of these approaches, we seek a pathway to transform knowledge production and application.

Yarime et al. (2012) suggested that we could be seeing a third academic revolution focused on science for action and a seamless multi-directional flow between education, research and action [154]. There will always be a need for traditional scientific endeavors that produce new insights about our world, new technological advances, and solutions to discrete problems, although they may be applied faster if they include stakeholders early in the process. As we face new and more complex types of problems that range in scale from the local to the global, and connect synergistically across scales, every action we take leads to repercussions in new and unexpected dimensions. In these problem-spaces where values, politics and culture intimately influence how we frame and manage problems, modern science alone cannot address these issues. This convergence of approaches at the confluence of research and practice is perhaps our best chance at creating strategies for problem management that are feasible, effective, and equitable. By cultivating a greater awareness of approaches that have historically linked science and society for action, we may better understand power relationships, the utility of working at different scales, and the social processes of knowledge creation.

The diversity of approaches reviewed here suggests a few considerations as TDA grows: (1) whose knowledge is primary? (2) how is power shared within projects? and (3) what is the appropriate scale for TDA projects? This review has demonstrated that prior knowledge/practice approaches have typically prioritized modern science. This implicit bias has been acknowledged by some [17], and they have called for leadership roles for practitioners. How would knowledge/practice approaches differ if these efforts were led and facilitated by practitioners with modern scientists/scholars as participants? Is there a need to question current funding structures that give decision-making authority to modern scientists/scholars instead of those who will apply the generated knowledge? If the goal of efforts is truly to lead to usable and transformative science, wouldn't this be more possible if practitioners and end-users controlled the process to confirm that it was a benefit? Finally, modern science often prioritizes projects that appear to have a broader impact or result in generalizable knowledge. As this review has shown, there are often tradeoffs between complexity, applicability, and generalizability. If the goal of TDA is to understand and inform real-world problem settings, then we should carefully approach scaling up and make sure that the knowledge generated fits and benefits the local context. We should also consider the importance of networks for exchanging the stories, experiences, and best management practices that arise in complex settings but whose lessons could be adapted to other settings.

This review highlights that TDA is not new, but a continuation of a suite of prior approaches that have sought to bridge knowledge and action. By exploring these antecedents and parallel approaches, we can see the threads that connect them, as well as the emergent and unanswered questions that could benefit from further application and exploration.

Author Contributions: All authors contributed to conceptualization, methodology, review, draft preparation and editing. J.A.K. and C.N.K. created figures, M.E.F.-G. conducted searches in Web of Science, and C.N.K. wrote the final draft and administered the project.

Funding: This research was funded by National Science Foundation, NSF \#DEB 1414106.

Acknowledgments: We would like to thank F.S. Chapin, K. Curran, and C. Wyborn for insightful reviews of this paper prior to submission. 
Conflicts of Interest: The authors declare no conflict of interest. The funders had no role in the design of the study; in the collection, analyses, or interpretation of data; in the writing of the manuscript, or in the decision to publish the results.

\section{Appendix A Search Terms for Each Approach}

We used the following search terms to locate papers affiliated with each of the reviewed approaches within Web of Science.

1. Citizen Science: "Citizen Science"

2. Collaborative Adaptive Management: "Collaborative Adaptive Management" and "Community Based Adaptive Management"

3. Evidence Based Practice: "Evidence Based Practice"

4. Indigenous and Local Knowledge: "Indigenous Science”, "Indigenous Knowledge”, “Traditional Ecological Knowledge"

5. Knowledge Integration: "Knowledge Integration", "Indigenous Knowledge", "Traditional Ecological Knowledge"

6. Knowledge to Action: "Knowledge to Action"

7. Participatory Action Research: "Participatory Action Research" and "Action Research"

8. Transdisciplinary: "Transdisciplinary Science" and "Transdisciplinary Knowledge"

9. Translational Science: "Translational Science"

\section{References}

1. Chapin, F.S.; Carpenter, S.R.; Kofinas, G.P.; Folke, C.; Abel, N.; Clark, W.C.; Olsson, P.; Smith, D.M.S.; Walker, B.; Young, O.R.; et al. Ecosystem Stewardship: Sustainability Strategies for a Rapidly Changing Planet. Trends Ecol. Evol. 2010, 25, 241-249. [CrossRef] [PubMed]

2. Gibbons, M.; Limoges, C.; Nowotny, H.; Schwartzman, S.; Scott, P.; Trow, M. The New Production of Knowledge: The Dynamics of Science and Research in Contemporary Societies; SAGE: London, UK, 2010.

3. Nowotny, H.; Scott, P.B.; Gibbons, M.T. Re-Thinking Science: Knowledge and the Public in an Age of Uncertainty, 1st ed.; Polity: London, UK, 2001.

4. Brandt, P.; Ernst, A.; Gralla, F.; Luederitz, C.; Lang, D.J.; Newig, J.; Reinert, F.; Abson, D.J.; von Wehrden, H. A Review of Transdisciplinary Research in Sustainability Science. Ecol. Econ. 2013, 92, 1-15. [CrossRef]

5. Mauser, W.; Klepper, G.; Rice, M.; Schmalzbauer, B.S.; Hackmann, H.; Leemans, R.; Moore, H. Transdisciplinary Global Change Research: The Co-Creation of Knowledge for Sustainability. Curr. Opin. Environ. Sustain. 2013, 5, 420-431. [CrossRef]

6. Klein, J.T. Prospects for Transdisciplinarity. Futures 2004, 36, 515-526. [CrossRef]

7. Wise, P.H.; Shaw, G.M.; Druzin, M.L.; Darmstadt, G.L.; Quaintance, C.; Mäkinen, E.; Relman, D.A.; Quake, S.R.; Butte, A.J.; Angst, M.S.; et al. Risky Business: Meeting the Structural Needs of Transdisciplinary Science. J. Pediatr. 2017, 191, 255-258. [CrossRef] [PubMed]

8. Miller, C.A.; Wyborn, C. Co-Production in Global Sustainability: Histories and Theories. Environ. Sci. Policy 2018. [CrossRef]

9. Cornell, S.; Berkhout, F.; Tuinstra, W.; Tàbara, J.D.; Jäger, J.; Chabay, I.; de Wit, B.; Langlais, R.; Mills, D.; Moll, P.; et al. Opening up Knowledge Systems for Better Responses to Global Environmental Change. Environ. Sci. Policy 2013, 28, 60-70. [CrossRef]

10. Kates, R.W.; Clark, W.C.; Corell, R.; Hall, J.M.; Jaeger, C.C.; Lowe, I.; McCarthy, J.J.; Schellnhuber, H.J.; Bolin, B.; Dickson, N.M.; et al. Sustainability Science. Science 2001, 292, 641-642. [CrossRef]

11. Westberg, L.; Polk, M. The Role of Learning in Transdisciplinary Research: Moving from a Normative Concept to an Analytical Tool through a Practice-Based Approach. Sustain. Sci. 2016, 11, 385-397. [CrossRef]

12. Scholz, R.W.; Steiner, G. The Real Type and Ideal Type of Transdisciplinary Processes: Part I-Theoretical Foundations. Sustain. Sci. 2015, 10, 527-544. [CrossRef]

13. Bernstein, J.H. Transdisciplinarity: A Review of Its Origins, Development, and Current Issues. J. Res. Pract. 2015, 11, 1. Available online: http:/jirp.icaap.org/index.php/jrp/article/view/510/412 (accessed on 4 September 2019). 
14. Kessel, F.; Rosenfield, P.L. Toward Transdisciplinary Research: Historical and Contemporary Perspectives. Am. J. Prev. Med. 2008, 35, S225-S234. [CrossRef] [PubMed]

15. Rosenfield, P.L. The Potential of Transdisciplinary Research for Sustaining and Extending Linkages Between the Health and Social Sciences. Soc. Sci. Med. 1992, 35, 1343-1357. [CrossRef]

16. Jantsch, E. Inter- and Transdisciplinary University: A Systems Approach to Education and Innovation. High. Educ. 1972, 1, 7-37. [CrossRef]

17. Pohl, C.; Hirsch Hadorn, G. Methodological Challenges of Transdisciplinary Research. Nat. Sci. Soc. 2008, 16, 111-121. [CrossRef]

18. Suni, T. Co-producing Research to Support Transformation to Sustainability 2017. Presented at the 2nd ICOS Science Conference, Helsinki, Finland, 27-29 September 2016; Available online: www.slideshare.net/ ICOS_RI/future-earth-coproducing-research-to-support-transformation-to-sustainability (accessed on 4 September 2019).

19. Balvanera, P.; Daw, T.; Gardner, T.; Martín-López, B.; Norström, A.; Ifejika Speranza, C.; Spierenburg, M.; Bennett, E.; Farfan, M.; Hamann, M.; et al. Key Features for More Successful Place-Based Sustainability Research on Social-Ecological Systems: A Programme on Ecosystem Change and Society (PECS) perspective. Ecol. Soc. 2017, 22, 14. [CrossRef]

20. Charlesworth, M.E. Transdisciplinary Solutions for Sustainable Development; Routledge: London, UK, 2017.

21. Enengel, B.; Muhar, A.; Penker, M.; Freyer, B.; Drlik, S.; Ritter, F. Co-Production of Knowledge in Transdisciplinary Doctoral Theses on Landscape Development-An Analysis of Actor Roles and Knowledge Types in Different Research Phases. Landsc. Urban. Plan. 2012, 105, 106-117. [CrossRef]

22. Klein, J.T.; Grossenbacher-Mansuy, W.; Häberli, R.; Bill, A.; Scholz, R.W.; Welti, M. (Eds.) Transdisciplinarity: Joint Problem Solving among Science, Technology, and Society: An. Effective Way for Managing Complexity; Birkhäuser: Basel, Switzerland, 2001.

23. Rice, M. Spanning Disciplinary, Sectoral and International Boundaries: A Sea Change towards Transdisciplinary Global Environmental Change Research? Curr. Opin. Environ. Sustain. 2013, 5, 409-419. [CrossRef]

24. Klenk, N.; Fiume, A.; Meehan, K.; Gibbes, C. Local Knowledge in Climate Adaptation Research: Moving Knowledge Frameworks from Extraction to Co-production: Local Knowledge in Climate Adaptation Research. Wiley Interdiscip. Rev. Clim. Chang. 2017, 8, e475. [CrossRef]

25. Schuttenberg, H.Z.; Guth, H.K. Seeking our Shared Wisdom: A Framework for Understanding Knowledge Coproduction and Coproductive Capacities. Ecol. Soc. 2015, 20, 15. [CrossRef]

26. Adler, C.; Hadorn, G.H.; Breu, T.; Wiesmann, U.; Pohl, C. Conceptualizing the Transfer of Knowledge across Cases in Transdisciplinary Research. Sustain. Sci. 2018, 13, 179-190. [CrossRef] [PubMed]

27. Aikenhead, G.S.; Ogawa, M. Indigenous Knowledge and Science Revisited. Cult. Stud. Sci. Educ. 2007, 2, 539-620. [CrossRef]

28. Kawagley, O.; Norris-Tull, D.; Norris-Tull, R.A. The Indigenous Worldview of Yupiaq Culture: Its Scientific Nature and Relevance to the Practice and Teaching of Science. J. Res. Sci. Teach. 1998, 35, 133-144. [CrossRef]

29. Ogawa, M. Science Education in a Multiscience Perspective. Sci. Educ. 1995, 79, 583-593. [CrossRef]

30. Berkes, F. Sacred Ecology: Traditional Ecological Knowledge and Resource Management; Taylor \& Francis: Oxfordshire, UK, 1999.

31. Johnson, J.T.; Howitt, R.; Cajete, G.; Berkes, F.; Louis, R.P.; Kliskey, A. Weaving Indigenous and Sustainability Sciences to Diversify Our Methods. Sustain. Sci. 2016, 11, 1-11. [CrossRef]

32. Cajete, G. Native Science: Natural Laws of Interdependence; Clear Light Publishers: Santa Fe, NM, USA, 2000.

33. Barnhardt, R.; Kawagley, A.O. Indigenous Knowledge Systems and Alaska Native Ways of Knowing. Anthropol. Educ. Q. 2005, 36, 8-23. [CrossRef]

34. Alaska Native Science Commission Alaska Native Science Commission. 1994. Available online: http: //www.nativescience.org/ (accessed on 15 September 2018).

35. Worldwide Indigenous Science Network Worldwide Indigenous Science Network. 1989. Available online: https:/wisn.org (accessed on 15 September 2018).

36. Whyte, K.P.; Brewer, J.P.; Johnson, J.T. Weaving Indigenous Science, Protocols and Sustainability Science. Sustain. Sci. 2016, 11, 25-32. [CrossRef]

37. Broadhead, L.-A.; Howard, S. Deepening the Debate over 'Sustainable Science': Indigenous Perspectives as a Guide on the Journey. Sustain. Dev. 2011, 19, 301-311. [CrossRef] 
38. Snively, G.; Corsiglia, J. Discovering Indigenous Science: Implications for Science Education. Sci. Educ. 2000, 85, 6-34. [CrossRef]

39. Chambers, R. The Origins and Practice of Participatory Rural Appraisal. World Dev. 1994, 22, $953-969$. [CrossRef]

40. Cornwall, A.; Jewkes, R. What is Participatory Research? Soc. Sci. Med. 1995, 41, 1667-1676. [CrossRef]

41. Arnold, J.S.; Fernandez-Gimenez, M. Building Social Capital Through Participatory Research: An Analysis of Collaboration on Tohono O'odham Tribal Rangelands in Arizona. Soc. Nat. Resour. 2007, 20, 481-495. [CrossRef]

42. Fortmann, L. Participatory Research in Conservation and Rural Livelihoods: Doing Science Together; John Wiley \& Sons: Hoboken, NJ, USA, 2009.

43. Fortmann, L.; Ballard, H. Sciences, Knowledges, and the Practice of Forestry. Eur. J. For. Res. 2011, 130, 467-477. [CrossRef]

44. Catalani, C.; Minkler, M. Photovoice: A Review of the Literature in Health and Public Health. Health Educ. Behav. 2010, 37, 424-451. [CrossRef] [PubMed]

45. Heras, M.; Tabara, J.D.; Meza, A. Performing Biospheric Futures with Younger Generations: A Case in the MAB Reserve of La Sepultura, Mexico. Ecol. Soc. 2016, 21, 14. [CrossRef]

46. Minkler, M. Using Participatory Action Research to Build Healthy Communities. Public Health Rep. 2000, 115, 191-197. [CrossRef]

47. Minkler, M.; Wallerstein, N. (Eds.) Community-Based Participatory Research for Health: From Process to Outcomes, 2nd ed.; Jossey-Bass: San Francisco, CA, USA, 2008.

48. Wilmsen, C.; Elmendorf, W.; Fisher, L.; Ross, J.; Sararthy, B.; Wells, G. Partnerships for Empowerment: Participatory Research for Community-Based Natural Resource Management; Earthscan: London, UK, 2008.

49. Reid, H. Ecosystem- and Community-Based Adaptation: Learning from Community-Based Natural Resource Management. Clim. Dev. 2016, 8, 4-9. [CrossRef]

50. Mosse, D. Authority, Gender and Knowledge: Theoretical Reflections on the Practice of Participatory Rural Appraisal. Dev. Chang. 1994, 25, 497-526. [CrossRef]

51. Leung, M.W.; Yen, I.H.; Minkler, M. Community Based Participatory Research: A Promising Approach for Increasing Epidemiology's Relevance in the 21st century. Int. J. Epidemiol. 2004, 33, 499-506. [CrossRef]

52. Mikesell, L.; Bromley, E.; Khodyakov, D. Ethical Community-Engaged Research: A Literature Review. Am. J. Public Health 2013, 103, e7-e14. [CrossRef]

53. Clark, W.C.; van Kerkhoff, L.; Lebel, L.; Gallopin, G.C. Crafting Usable Knowledge for Sustainable Development. Proc. Natl. Acad. Sci. USA 2016, 113, 4570-4578. [CrossRef] [PubMed]

54. Matson, P.; Clark, W.C.; Andersson, K. Pursuing Sustainability: A Guide to the Science and Practice, 1st ed.; Princeton University Press: Princeton, NJ, USA, 2016.

55. Van Kerkhoff, L.; Lebel, L. Linking Knowledge and Action for Sustainable Development. Annu. Rev. Environ. Resour. 2006, 31, 445-477. [CrossRef]

56. Booth, T. Researching Policy Research: Issues of Utilization in Decision Making. Knowledge 1990, 12, 80-100. [CrossRef]

57. Albæk, E. Between Knowledge and Power: Utilization of Social Science in Public Policy Making. Policy Sci. 1995, 28, 79-100. [CrossRef]

58. Perkins, D.N. Knowledge as Design, 1st ed.; Lawrence Erlbaum Associates: Hillsdale, NY, USA, 1986.

59. Van Kerkhoff, L. Developing Integrative Research for Sustainability Science through a Complexity Principles-Based Approach. Sustain. Sci. 2014, 9, 143-155. [CrossRef]

60. Wickson, F.; Carew, A.L.; Russell, A.W. Transdisciplinary Research: Characteristics, Quandaries and Quality. Futures 2006, 38, 1046-1059. [CrossRef]

61. Lang, D.J.; Wiek, A.; Bergmann, M.; Stauffacher, M.; Martens, P.; Moll, P.; Swilling, M.; Thomas, C.J. Transdisciplinary Research in Sustainability Science: Practice, Principles, and Challenges. Sustain. Sci. 2012, 7, 25-43. [CrossRef]

62. Norberg, J.; Cumming, G. Complexity Theory for a Sustainable Future; Columbia University Press: New York, NY, USA, 2008.

63. Cash, D.W.; Clark, W.C.; Alcock, F.; Dickson, N.M.; Eckley, N.; Guston, D.H.; Jäger, J.; Mitchell, R.B. Knowledge Systems for Sustainable Development. Proc. Natl. Acad. Sci. USA 2003, 100, 8086-8091. [CrossRef] [PubMed] 
64. Posner, S.M.; McKenzie, E.; Ricketts, T.H. Policy Impacts of Ecosystem Services Knowledge. Proc. Natl. Acad. Sci. USA 2016, 113, 1760-1765. [CrossRef] [PubMed]

65. McGreavy, B.; Hutchins, K.; Smith, H.; Lindenfeld, L.; Silka, L. Addressing the Complexities of Boundary Work in Sustainability Science through Communication. Sustainability 2013, 5, 4195. [CrossRef]

66. Young, J.C.; Waylen, K.A.; Sarkki, S.; Albon, S.; Bainbridge, I.; Balian, E.; Davidson, J.; Edwards, D.; Fairley, R.; Margerison, C.; et al. Improving the Science-Policy Dialogue to Meet the Challenges of Biodiversity Conservation: Having Conversations Rather than Talking at One-Another. Biodivers. Conserv. 2014, 23, 387-404. [CrossRef]

67. Kuhn, T.S. The Structure of Scientific Revolutions, 2nd ed.; University of Chicago Press: Chicago, IL, USA, 1970.

68. Knorr-Cetina, K. The Manufacture of Knowledge: An Essay on the Constructivist and Contextual Nature of Science; Pergamon International Library of Science, Technology, Engineering, and Social Studies, Pergamon Press: Elmsford, NY, USA, 1981.

69. Latour, B.; Woolgar, S.; Salk, J. Laboratory Life: The Construction of Scientific Facts, 2nd ed.; Princeton University Press: Princeton, NJ, USA, 1986.

70. Gunderson, L.H.; Holling, C.S. Panarchy: Understanding Transformations in Human and Natural Systems; Island Press: Washington, DC, USA, 2002.

71. Warren, D.M.; Rajasekaran, B. Putting Local Knowledge to Good Use. Int. Agric. Dev. 1993, 13, 8-10.

72. Berkes, F. Traditional ecological knowledge in perspective. In Traditional Ecological Knowledge: Concepts and Cases; Canadian Museum of Nature/International Development Research Centre: Ottawa, ON, Canada, 1993; pp. 1-9.

73. Ingold, T. The Perception of the Environment: Essays on Livelihood, Dwelling and Skill; Psychology Press: East Sussex, UK, 2000.

74. Agrawal, A. Dismantling the Divide Between Indigenous and Scientific Knowledge. Dev. Chang. 1995, 26, 413-439. [CrossRef]

75. Murdoch, J.; Clark, J. Sustainable Knowledge. Geoforum 1994, 25, 115-132. [CrossRef]

76. Turnbull, D. Local Knowledge and Comparative Scientific Traditions. Knowl. Policy 1993, 6, 29-54. [CrossRef]

77. Brook, R.K.; McLachlan, S.M. Trends and Prospects for Local Knowledge in Ecological and Conservation Research and Monitoring. Biodivers. Conserv. 2008, 17, 3501-3512. [CrossRef]

78. Mistry, J.; Berardi, A. Bridging Indigenous and Scientific Knowledge. Science 2016, 352, 1274-1275. [CrossRef]

79. Nadasdy, P. The Politics of TEK: Power and the "Integration" of Knowledge. Arct. Anthropol. 1999, 36, 1-18.

80. Blaikie, P.; Brown, K.; Stocking, M.; Tang, L.; Dixon, P.; Sillitoe, P. Knowledge in Action: Local Knowledge as a Development Resource and Barriers to its Incorporation in Natural Resource Research and Development. Agric. Syst. 1997, 55, 217-237. [CrossRef]

81. Tengö, M.; Hill, R.L.; Malmer, P.; Raymond, C.M.; Spierenburg, M.; Danielsen, F.; Elmqvist, T.; Folke, C. Weaving Knowledge Systems in IPBES, CBD and beyond-Lessons Learned for Sustainability. Curr. Opin. Environ. Sustain. 2017, 26, 17-25. [CrossRef]

82. Knapp, C.N.; Fernandez-Gimenez, M.; Kachergis, E.; Rudeen, A. Using Participatory Workshops to Integrate State-and-Transition Models Created with Local Knowledge and Ecological Data. Rangel. Ecol. Manag. 2011, 64, 158-170. [CrossRef]

83. Simpson, L.R. Anticolonial Strategies for the Recovery and Maintenance of Indigenous Knowledge. Am. Indian Q. 2004, 28, 373-384. [CrossRef]

84. Cruikshank, J. Are Glaciers 'Good to Think With'? Recognising Indigenous Environmental Knowledge. Anthropol. Forum 2012, 22, 239-250. [CrossRef]

85. Thornton, T.; Scheer, A. Collaborative Engagement of Local and Traditional Knowledge and Science in Marine Environments: A Review. Ecol. Soc. 2012, 17, 8. [CrossRef]

86. Bohensky, E.L.; Maru, Y. Indigenous Knowledge, Science, and Resilience: What Have We Learned from a Decade of International Literature on "Integration"? Ecol. Soc. 2011, 16, 6. [CrossRef]

87. Raymond, C.M.; Fazey, I.; Reed, M.S.; Stringer, L.C.; Robinson, G.M.; Evely, A.C. Integrating Local and Scientific Knowledge for Environmental Management. J. Environ. Manag. 2010, 91, 1766-1777. [CrossRef] [PubMed]

88. Davidson-Hunt, I.J. Adaptive Learning Networks: Developing Resource Management Knowledge through Social Learning Forums. Hum. Ecol. 2006, 34, 593-614. [CrossRef] 
89. Tengö, M.; Brondizio, E.S.; Elmqvist, T.; Malmer, P.; Spierenburg, M. Connecting Diverse Knowledge Systems for Enhanced Ecosystem Governance: The Multiple Evidence Base Approach. AMBIO 2014, 43, 579-591. [CrossRef]

90. Fazey, I.; Evely, A.C.; Reed, M.S.; Stringer, L.C.; Kruijsen, J.; White, P.C.L.; Newsham, A.; Jin, L.; Cortazzi, M.; Phillipson, J.; et al. Knowledge exchange: A review and research agenda for environmental management. Environ. Conserv. 2013, 40, 19-36. [CrossRef]

91. Rubio, D.M.; Schoenbaum, E.E.; Lee, L.S.; Schteingart, D.E.; Marantz, P.R.; Anderson, K.E.; Platt, L.D.; Baez, A.; Esposito, K. Defining Translational Research: Implications for Training. Acad. Med. J. Assoc. Am. Med. Coll. 2010, 85, 470-475. [CrossRef]

92. Schlesinger, W.H. Translational Ecology. Science 2010, 329, 609. [CrossRef] [PubMed]

93. Enquist, C.A.; Jackson, S.T.; Garfin, G.M.; Davis, F.W.; Gerber, L.R.; Littell, J.A.; Tank, J.L.; Terando, A.J.; Wall, T.U.; Halpern, B.; et al. Foundations of Translational Ecology. Front. Ecol. Environ. 2017, 15, 541-550. [CrossRef]

94. Wall, T.U.; McNie, E.; Garfin, G.M. Use-Inspired Science: Making Science Usable by and Useful to Decision Makers. Front. Ecol. Environ. 2017, 15, 551-559. [CrossRef]

95. Satterfield, J.M.; Spring, B.; Brownson, R.C.; Mullen, E.J.; Newhouse, R.P.; Walker, B.B.; Whitlock, E.P. Toward a Transdisciplinary Model of Evidence-Based Practice. Milbank Q. 2009, 87, 368-390. [CrossRef] [PubMed]

96. Newhouse, R.P.; Spring, B. Interdisciplinary Evidence-based Practice: Moving from Silos to Synergy. Nurs. Outlook 2010, 58, 309-317. [CrossRef] [PubMed]

97. Pullin, A.S.; Knight, T.M. Effectiveness in Conservation Practice: Pointers from Medicine and Public Health. Conserv. Biol. 2001, 15, 50-54. [CrossRef]

98. Pullin, A.S.; Knight, T.M. Doing More Good than Harm-Building an Evidence-Base for Conservation and Environmental Management. Biol. Conserv. 2009, 142, 931-934. [CrossRef]

99. Walsh, J.; Dicks, L.; Sutherland, W.J. The Effect of Scientific Evidence on Conservation Practitioners' Management Decisions. Conserv. Biol. 2014, 29, 88-98. [CrossRef] [PubMed]

100. Knight, A.T.; Cowling, R.M.; Rouget, M.; Balmford, A.; Lombard, A.T.; Campbell, B.M. Knowing but not doing: Selecting priority conservation areas and the research-implementation gap. Conserv. Biol. J. Soc. Conserv. Biol. 2008, 22, 610-617. [CrossRef] [PubMed]

101. Arlettaz, R.; Schaub, M.; Fournier, J.; Reichlin, T.S.; Sierro, A.; Watson, J.E.M.; Braunisch, V. From Publications to Public Actions: When Conservation Biologists Bridge the Gap between Research and Implementation. BioScience 2010, 60, 835-842. [CrossRef]

102. Bonney, R. Citizen Science: A Lab Tradition. Living Bird Study Conserv. Birds 1996, 15, 7-15.

103. Irwin, A. Citizen Science: A Study of People, Expertise and Sustainable Development; Psychology Press: East Sussex, UK, 1995.

104. Bonney, R.; Cooper, C.B.; Dickinson, J.; Kelling, S.; Phillips, T.; Rosenberg, K.V.; Shirk, J. Citizen Science: A Developing Tool for Expanding Science Knowledge and Scientific Literacy. BioScience 2009, 59, 977-984. [CrossRef]

105. Bonney, R.; Shirk, J.L.; Phillips, T.B.; Wiggins, A.; Ballard, H.L.; Miller-Rushing, A.J.; Parrish, J.K. Next Steps for Citizen Science. Science 2014, 343, 1436-1437. [CrossRef] [PubMed]

106. Ballard, H.L.; Robinson, L.D.; Young, A.N.; Pauly, G.B.; Higgins, L.M.; Johnson, R.F.; Tweddle, J.C. Contributions to Conservation Outcomes by Natural History Museum-Led Citizen Science: Examining Evidence and Next Steps. Biol. Conserv. 2017, 208, 87-97. [CrossRef]

107. Danielsen, F.; Burgess, N.D.; Jensen, P.M.; Pirhofer-Walzl, K. Environmental Monitoring: The Scale and Speed of Implementation Varies According to the Degree of Peoples Involvement. J. Appl. Ecol. 2010, 47, 1166-1168. [CrossRef]

108. Carr, A.J.L. Why do we all need community science? Soc. Nat. Resour. 2004, 17, 841-849. [CrossRef]

109. Shirk, J.L.; Ballard, H.L.; Wilderman, C.C.; Phillips, T.; Wiggins, A.; Jordan, R.; McCallie, E.; Minarchek, M.; Lewenstein, B.V.; Krasny, M.E.; et al. Public Participation in Scientific Research: A Framework for Deliberate Design. Ecol. Soc. 2012, 17, 29. [CrossRef]

110. McKinley, D.C.; Miller-Rushing, A.J.; Ballard, H.L.; Bonney, R.; Brown, H.; Cook-Patton, S.C.; Evans, D.M.; French, R.A.; Parrish, J.K.; Phillips, T.B.; et al. Citizen Science can Improve Conservation Science, Natural Resource Management, and Environmental Protection. Biol. Conserv. 2017, 208, 15-28. [CrossRef] 
111. Lintott, C.J.; Schawinski, K.; Slosar, A.; Land, K.; Bamford, S.; Thomas, D.; Jordan Raddick, M.; Nichol, R.C.; Szalay, A.; Andreescu, D.; et al. Galaxy Zoo: Morphologies derived from visual inspection of galaxies from the Sloan Digital Sky Survey. Mon. Not. R. Astron. Soc. 2008, 389, 1179-1189. [CrossRef]

112. Schwartz, M.D.; Betancourt, J.L.; Weltzin, J.F. From Caprio's lilacs to the USA National Phenology Network. Front. Ecol. Environ. 2012, 10, 324-327. [CrossRef]

113. Bela, G.; Peltola, T.; Young, J.C.; Balázs, B.; Arpin, I.; Pataki, G.; Hauck, J.; Kelemen, E.; Kopperoinen, L.; Van Herzele, A.; et al. Learning and the transformative potential of citizen science: Lessons from the Study of Nature. Conserv. Biol. 2016, 30, 990-999. [CrossRef] [PubMed]

114. Couvet, D.; Prevot, A.-C. Citizen-science programs: Towards transformative biodiversity governance. Environ. Dev. 2015, 13, 39-45. [CrossRef]

115. Chandler, M.; See, L.; Copas, K.; Bonde, A.M.Z.; López, B.C.; Danielsen, F.; Legind, J.K.; Masinde, S.; Miller-Rushing, A.J.; Newman, G.; et al. Contribution of Citizen Science towards International Biodiversity Monitoring. Biol. Conserv. 2017, 213, 280-294. [CrossRef]

116. Daniels, S.E.; Walker, G.B. Lessons from the Trenches: Twenty Years of Using Systems Thinking in Natural Resource Conflict Situations: Systems Thinking and Natural Resource Conflict. Syst. Res. Behav. Sci. 2012, 29, 104-115. [CrossRef]

117. Wondolleck, J.M.; Yaffee, S.L. Making Collaboration Work: Lessons from Innovation in Natural Resource Managment; Island Press: Washington, DC, USA, 2000.

118. Holling, C.S. Adaptive Environmental Assessment and Management; International Institute for Applied Systems Analysis: Laxenburg, Austria, 1978.

119. Plummer, R.; Crona, B.; Armitage, D.; Olsson, P.; Tengö, M.; Yudina, O. Adaptive Comanagement: A Systematic Review and Analysis. Ecol. Soc. 2012, 17, 11. [CrossRef]

120. Colfer, C.J.P. The Complex Forest: Communities, Uncertainty, and Adaptive Collaborative Management; Resources for the Future and the Center for International Forestry Research (CIFOR): Washington, DC, USA, 2005.

121. Armitage, D.; Marschke, M.; Plummer, R. Adaptive Co-Management and the Paradox of Learning. Glob. Environ. Chang. 2008, 18, 86-98. [CrossRef]

122. Daniels, S.E.; Walker, G.B. Working through Environmental Conflict: The Collaborative Learning Approach by Steven E. Daniels and Gregg B. Walker; Praeger Publishers: Westport, CT, USA, 2001.

123. Innes, J.L.; Booher, D.E. Planning with Complexity: An Introduction to Collaborative Rationality for Public Policy; Routledge: New York, NY, USA, 2010.

124. Fernandez-Gimenez, M.; Ballard, H.; Sturtevant, V. Adaptive Management and Social Learning in Collaborative and Community-Based Monitoring: A Study of Five Community-Based Forestry Organizations in the western USA. Ecol. Soc. 2008, 13, 4. [CrossRef]

125. Reed, M.; Evely, A.; Cundill, G.; Fazey, I.; Glass, J.; Laing, A.; Newig, J.; Parrish, B.; Prell, C.; Raymond, C.; et al. What is Social Learning? Ecol. Soc. 2010, 15, r1. [CrossRef]

126. Wilmer, H.; Derner, J.D.; Fernández-Giménez, M.E.; Briske, D.D.; Augustine, D.J.; Porensky, L.M. Collaborative Adaptive Rangeland Management Fosters Management-Science Partnerships. Rangel. Ecol. Manag. 2018, 71, 646-657. [CrossRef]

127. McLain, R.J.; Lee, R.G. Adaptive management: Promises and pitfalls. Environ. Manag. 1996, 20, 437-448. [CrossRef]

128. Stankey, G.H.; Bormann, B.T.; Ryan, C.; Shindler, B.; Sturtevant, V.; Clark, R.N.; Philpot, C. Adaptive management and the Northwest Forest Plan: Rhetoric and reality. J. For. 2003, 1011, 40-46.

129. Williams, B.K. Adaptive Management of Natural Resources-Framework and Issues. J. Environ. Manag. 2011, 92, 1346-1353. [CrossRef] [PubMed]

130. Susskind, L.; Camacho, A.E.; Schenk, T. A critical assessment of collaborative adaptive management in practice: Collaborative adaptive management. J. Appl. Ecol. 2012, 49, 47-51. [CrossRef]

131. Rist, L.; Felton, A.; Samuelsson, L.; Sandström, C.; Rosvall, O. A New Paradigm for Adaptive Management. Ecol. Soc. 2013, 18, 63. [CrossRef]

132. Fernández-Giménez, M.E.; Augustine, D.J.; Porensky, L.M.; Wilmer, H.; Derner, J.D.; Briske, D.D.; Olsgard Stewart, M. Complexity fosters learning in collaborative adaptive management. Ecol. Soc. 2019, 24, 29. [CrossRef] 
133. Muñoz-Erickson, T.A.; Aguilar-González, B.; Loeser, M.R.R.; Sisk, T.D. A Framework to Evaluate Ecological and Social Outcomes of Collaborative Management: Lessons from Implementation with a Northern Arizona Collaborative Group. Environ. Manag. 2010, 45, 132-144. [CrossRef] [PubMed]

134. Roux, D.J.; Nel, J.L.; Cundill, G.; O’Farrell, P.; Fabricius, C. Transdisciplinary research for systemic change: Who to learn with, what to learn about and how to learn. Sustain. Sci. 2017, 12, 711-726. [CrossRef]

135. Ballard, H.L.; Belsky, J.M. Participatory action research and environmental learning: Implications for resilient forests and communities. Environ. Educ. Res. 2010, 16, 611-627. [CrossRef]

136. Plummer, R.; Armitage, D. A resilience-based framework for evaluating adaptive co-management: Linking ecology, economics and society in a complex world. Ecol. Econ. 2007, 61, 62-74. [CrossRef]

137. Rotman, D.; Preece, J.; Hammock, J.; Procita, K.; Hansen, D.; Parr, C.; Lewis, D.; Jacobs, D. Dynamic changes in motivation in collaborative citizen-science projects. In Proceedings of the ACM 2012 Conference on Computer Supported Cooperative Work-CSCW'12; ACM Press: Seattle, WA, USA, 2012; p. 217.

138. Dickinson, J.L.; Shirk, J.; Bonter, D.; Bonney, R.; Crain, R.L.; Martin, J.; Phillips, T.; Purcell, K. The current state of citizen science as a tool for ecological research and public engagement. Front. Ecol. Environ. 2012, 10, 291-297. [CrossRef]

139. Hoffmann, S.; Pohl, C.; Hering, J.G. Methods and procedures of transdisciplinary knowledge integration: Empirical insights from four thematic synthesis processes. Ecol. Soc. 2017, 22, 27. [CrossRef]

140. Read, E.K.; O’Rourke, M.; Hong, G.S.; Hanson, P.C.; Winslow, L.A.; Crowley, S.; Brewer, C.A.; Weathers, K.C. Building the team for team science. Ecosphere 2016, 7, e01291. [CrossRef]

141. Jahn, T.; Bergmann, M.; Keil, F. Transdisciplinarity: Between mainstreaming and marginalization. Ecol. Econ. 2012, 79, 1-10. [CrossRef]

142. Max-Neef, M.A. Foundations of Transdisciplinarity. Ecol. Econ. 2005, 53, 5-16. [CrossRef]

143. Stokols, D. Toward a Science of Transdisciplinary Action Research. Am. J. Community Psychol. 2006, 38, 79-93. [CrossRef]

144. Campos, I.S.; Alves, F.M.; Dinis, J.; Truninger, M.; Vizinho, A.; Penha-Lopes, G. Climate adaptation, transitions, and socially innovative action-research approaches. Ecol. Soc. 2016, 21, 13. [CrossRef]

145. Collins, P.H. Black Feminist Thought: Knowledge, Consciousness, and the Politics of Empowerment; Routledge: London, UK, 1990.

146. Haraway, D. Situated Knowledges: The Science Question in Feminism and the Privilege of Partial Perspective. Fem. Stud. 1988, 14, 575-599. [CrossRef]

147. Mignolo, W. The Darker Side of Western Modernity: Global Futures, Decolonial Options; Duke University Press: Durham, NC, USA, 2011.

148. Quijano, A.; Ennis, M. Coloniality of Power, Eurocentrism, and Latin America: Nepantla Views from South. S. Afr. J. High. Educ. 2000, 1, 533-580.

149. Habermas, J. Knowledge E Human Interests, 2nd ed.; Beacon Press: Boston, MA, USA, 1972.

150. Scarlett, L.; McKinney, M. Connecting People and Places: The Emerging Role of Network Governance in Large Landscape Conservation. Front. Ecol. Environ. 2016, 14, 116-125. [CrossRef]

151. Bednarek, A.T.; Wyborn, C.; Cvitanovic, C.; Meyer, R.; Colvin, R.M.; Addison, P.F.E.; Close, S.L.; Curran, K.; Farooque, M.; Goldman, E.; et al. Boundary Spanning at the Science-Policy Interface: The Practitioners' Perspectives. Sustain. Sci. 2018, 13, 1175-1183. [CrossRef]

152. Posner, P.L. The Pracademic: An Agenda for Re-Engaging Practitioners and Academics. Public Budg. Financ. 2009, 29, 12-26. [CrossRef]

153. Sandmann, L.R.; Thornton, C.H.; Jaeger, A.J. Institutionalizing Community Engagement in Higher Education: The First Wave of Carnegie Classified Institutions; Brown University: Providence, RI, USA, 2011.

154. Yarime, M.; Trencher, G.; Mino, T.; Scholz, R.W.; Olsson, L.; Ness, B.; Frantzeskaki, N.; Rotmans, J. Establishing Sustainability Science in Higher Education Institutions: Towards an Integration of Academic Development, Institutionalization, and Stakeholder Collaborations. Sustain. Sci. 2012, 7, 101-113. [CrossRef]

(C) 2019 by the authors. Licensee MDPI, Basel, Switzerland. This article is an open access article distributed under the terms and conditions of the Creative Commons Attribution (CC BY) license (http://creativecommons.org/licenses/by/4.0/). 